\title{
Role of microplankton in the diet and daily ration of Antarctic zooplankton species during austral summer
}

\author{
P. W. Froneman ${ }^{1, *}$, E. A. Pakhomov ${ }^{1}$, R. Perissinotto ${ }^{2}$, C. D. McQuaid ${ }^{1}$ \\ 'Southern Ocean Group, Department of Zoology and Entomology, Rhodes University, PO Box 94, \\ Grahamstown 6140, South Africa \\ ${ }^{2}$ Department of Zoology, University of Fort Hare, Private Bag X 1314, Alice 5700, South Africa
}

\begin{abstract}
Predation rates of the 9 most abundant Antarctic meso- (4 copepods) and macrozooplankton ( 3 euphausiids, 1 hyperiid and 1 salp) species on microplankton $(20$ to $200 \mu \mathrm{m}$ ) were estimated using in vitro incubations during the fourth cruise of the South African Antarctic Marine Ecosystem Study (SAAMES IV) to the ice-edge region of the Lazarev Sea during austral summer (Dec/Jan) 1994/1995. Chlorophyll a concentrations during the incubations ranged between 0.187 and $1.410 \mu \mathrm{g} \mathrm{l}^{-1}$ and were dominated by ice-associated chain-forming microphytoplankton ( $>20 \mu \mathrm{m}$ ) of the genera Nitzschia and Chaetoceros. The microplankton assemblages were entirely dominated by protozoans comprised of ciliates and dinoflagellates. Densities of protozoans ranged from 1375 to 2690 cells l$^{-1}$ Based on previously published results, meso- and macrozooplankton species generally consumed $>120 \%$ of their minimum daily ration, i.e. minimum carbon uptake (MCU), when offered microplankton. Exceptions were Euphausia crystallorophias and Vibilia antarctica for which microplankton carbon contributed 68 and $30 \%$ of MCU, respectively. Microplankton carbon contributed between 17 and $24 \%$ of the total carbon requirements for the 4 copepod species examined and between 21 and $73 \%$ for the macrozooplankton. The daily rations of juveniles were, however, twice those of the adults, suggesting that the relative importance of microzooplankton to the daily ration of macrozooplankton shifts with life stage. Carnivory by metazoan grazers may, therefore, potentially reduce the high grazing impact of microzooplankton on the local phytoplankton stock.
\end{abstract}

KEY WORDS: Antarctica C Carnivory $\cdot$ Zooplankton $\cdot$ Microzooplankton

\section{INTRODUCTION}

Recent observations have shown that the role of microzooplankton $(20$ to $200 \mu \mathrm{m}$ ) in aquatic food webs is more important than previously thought. Microzooplankton consume a significant proportion of daily primary production (Paranjape 1990, Froneman \& Perissinotto 1996, in press, for review see Pierce \& Turner 1992) and are important agents in nutrient regeneration (Probyn 1987, Goeyens et al. 1991). In addition to these roles, microzooplankton are considered to be an important source of carbon for larger zooplankton (Stoecker \& Capuzzo 1990). Since microzoo-

•E-mail: zopf@warthog.ru.ac.za plankton consume bactivorous flagellates, they may be regarded as important trophic intermediaries between bacterioplankton and larger meso- and macrozooplankton (Gifford \& Dagg 1988, 1990). On the basis of these observations, the classical paradigm of pelagic food webs simply composed of diatoms, copepods and fish has been revised (Sherr \& Sherr 1984).

Microzooplankton are an ubiquitous component of the plankton assemblages in the Southern Ocean (Garrison 1991, Garrison et al. 1993) and are now recognised as major consumers of phytoplankton production (Bjornsen \& Kuparinen 1991, Garrison et al. 1993, Burkill et al. 1995, Froneman \& Perissinotto 1996, in press). Phytoplankton consumed by microzooplankton contribute less to particulate organic flux due to the 
close association between microzooplankton, nanoflagellates and bacteria (microbial loop) which results in the recycling of carbon in the surface waters. Thus, in regions where microzooplankton represent the most important grazers of phytoplankton production, the biologically mediated carbon flux, the so called biological pump, is inefficient (Longhurst 1991). Grazing by larger zooplankton on microzooplankton may, however, represent an important source of carbon that can potentially be transferred from the microbial loop to the long-living pool in the deep ocean.

Feeding studies of larger zooplankton in the Southern Ocean have largely used the gut fluorescence technique to estimate daily rations and grazing impact (Conover \& Huntley 1991, Perissinotto 1992). Because the gut florescence technique uses chlorophyll and its degradation products as indices of feeding, the contribution of heterotrophic food items, e.g micro- and mesozooplankton, to total daily carbon intake is not measured. Consequently, the daily rations of these grazers may be substantially underestimated using this method alone. Indeed, energy budgets for the dominant Antarctic grazer Euphausia superba and some copepod species show that carbon derived from the grazing of phytoplankton alone can hardly meet the daily metabolic requirements (Bathmann et al. 1993, Drits \& Pasternak 1993, E. Pakhomov, R. Perissinotto, P. Froneman \& D. Miller unpubl., R. Perissinotto, E. Pakhomov, C. McQuaid \& P. Froneman unpubl.). These data suggest that other sources of carbon are important in meeting the energy demands of Antarctic zooplankton.

Gut content analysis of the dominant grazers in the vicinity of the marginal ice zone has repeatedly shown that protozoans comprise a significant proportion of the total number of items identified (Hopkins \& Torres 1989, Hopkins et al. 1993). A recent study has shown that protozoans constitute $-25 \%$ of the total identifiable items in the gut of the 2 dominant Antarctic euphausiids, Euphausia crystallorophias (Pakhomov et al. in press) and E. superba (Perissinotto et al. un.publ.), in the Atlantic sector of the Southern Ocean. These estimates are, however, likely to be gross underestimations due to the fragility of microzooplankton components (Tanoue \& Hara 1986). Also, these studies do not provide any quantitative data on the grazing impact of the 2 euphausids on microzooplankton or the contribution of these organisms to their daily energy intake.
Although several quantitative studies of zooplankton feeding on microzooplankton have been carried out in the northern hemisphere (Stoecker et al. 1987, Tiseleus 1989, Jeong 1994, Wickham 1995), few data are available for the southern hemisphere. A recent in vitro grazing study, conducted by Atkinson (1994), has shown that the consumption of dinoflagellates, ciliates and cryptomonads by the dominant copepods in the shelf region of South Georgia contributes a median of $43 \%$ of their total carbon uptake. Furthermore, this study has suggested that larger copepods consume microzooplankton at rates equivalent to those observed using diatoms of similar size (Atkinson 1994, Atkinson \& Shreeve 1995). Small copepods, however, appear to feed selectively on motile taxa such as protozoans (Atkinson 1994, 1995). At present, no data on the grazing impact of larger zooplankton on microzooplankton are available.

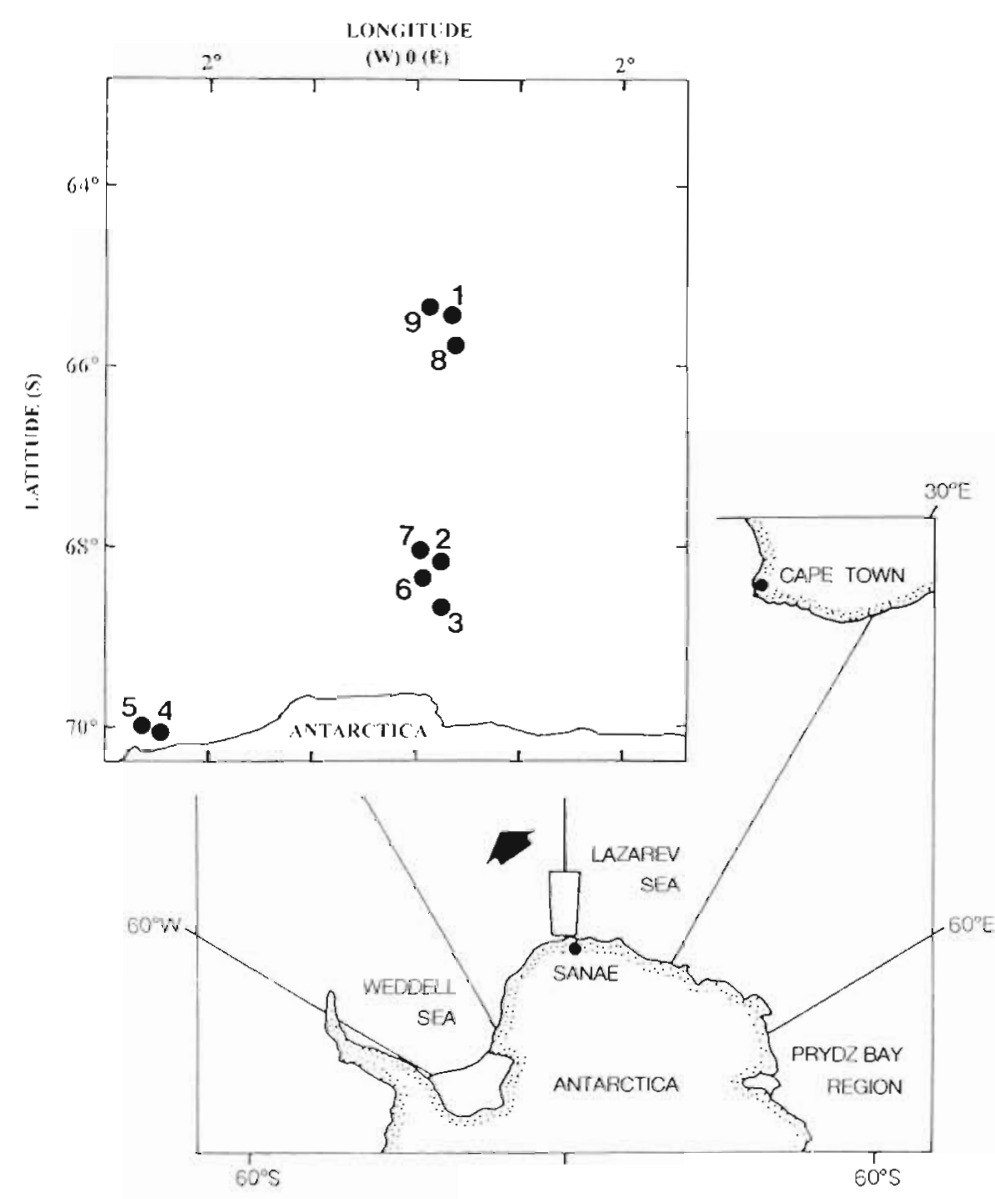

Fig. 1. Study area and inset jllustrating positions of the stations where carnivory experiments were carried out during the SAAMES IV cruise to the region of the ice-edge zone of the Lazarev Sea in austral summer (Dec/Jan) 1994/1995. (1) Euphausia superba; (2) Salpa thompsoni (3) Thysanoessa macrura; (4) Euphausia crystallorophias; (5) Calanus propinquus; (6) Metrida gerlachei; (7) Rhincalanus gigas; (8) Calanoldes acutus; (9) Vibilia antarctica 
The aim of our study is to present quantitative grazing data on the most abundant meso- and macroplankton species feeding on microzooplankton in the vicinity of the Marginal Ice Zone (MIZ) of the Lazarev Sea during austral summer 1995.

\section{MATERIALS AND METHODS}

Carnivory experiments with selected meso- and macrozooplankton on microplankton (20 to $200 \mu \mathrm{m}$ ) were conducted during the fourth South African Antarctic Marine Ecosystem Study (SAAMES IV) cruise in the MIZ of the Lazarev Sea during summer (Dec/Jan) 1994/1995 (Fig. 1). The consumption of microzooplankton was estimated employing the techniques of Gifford \& Dagg $(1988,1990)$. The predation impact of the 5 most abundant macrozooplankton species, adult Euphausia crystallorophias, juvenile E. superba, Thysanoessa macrura (adults and juveniles), the hyperiid Vibilia antarctica (adults) and the aggregate form of the tunicate Salpa thompsoni, were investigated. In addition, rates of carnivory by the 4 dominant Antarctic copepod species, Rhincalanus gigas, Metridia gerlachei, Calanus propinquus and Calanoides acutus, were also measured.

Zooplankton were collected with net tows $1500 \mu \mathrm{m}$ Bongo nets) and acclimated in natural seawater for $24 \mathrm{~h}$ in $20 \mathrm{l}$ polyethylene carboys under ambient conditions. Prior to the onset of the carnivory experiments, 6 replicate samples were prepared in 201 polyethylene containers filled with natural seawater and allowed to stand for $2 \mathrm{~h}$. According to Gifford (1993), this time period is sufficient to allow the stabilization of the plankton assemblage in the containers.

For each macrozooplankton carnivory experiment, 2 replicate samples in 20 l polyethylene carboys containing only natural seawater were used as controls. In the experimental treatments, 4 replicate samples, each containing 1 macrozooplankton individual, were used. The controls and treatments were then incubated on deck under ambient conditions for $24 \mathrm{~h}$. Each container was gently stirred with a plastic spatula at $6 \mathrm{~h}$ intervals to prevent the settlement of plankton. The same procedure was followed in the mesozooplankton carnivory experiments, except that 3 to 8 animals (see Table 1) were incubated in $2 \mathrm{l}$ polyethylene containers.

At the beginning of the experiment, two $250 \mathrm{ml}$ water samples were taken from each container for the determination of initial chlorophyll a (chl a) concentration and microzooplankton species composition and abundance. This procedure was repeated at the end of the experiments to estimate the final chl a concentration and microplankton densities. Chl a concentrations were determined fluorometrically (Turner 111 fluo- rometer) after extraction in 100\% methanol for $6 \mathrm{~h}$ (Holm-Hansen \& Riemann 1978).

Water samples for the determination of microplankton species composition and abundance were fixed with 10\% Lugol's solution (Leakey et al. 1994). Microplankton species composition and densities were estimated within 6 mo of collection using the Utermöhl settling technique after sedimentation in a $10 \mathrm{ml}$ settling chamber (Reid 1983). From each sample, 3 subsamples of $10 \mathrm{ml}$, representing $30 \%$ of the total, were counted. A Nikon TMS inverted microscope operated at $400 \times$ magnification was used for this analysis. A minimum of 100 fields or 500 cells was counted for each sample. No distinction between the autotrophic and heterotrophic components of the microplankton assemblages were made. The total carbon of the microplankton fraction was estimated by calculating the mean biovolume of 50 ciliates and 50 dinoflagellates (Boltovskoy et al. 1989). The carbon biomass of the microzooplankton was then estimated assuming that $1 \mu^{3}=0.19 \mathrm{pg} \mathrm{C}$ (Putt \& Stoecker 1989, SimeNgando et al. 1992).

In all experimental treatments, meso- and macrozooplankton organisms were preserved in buffered formalin at the end of the incubation period. The dry weight of all specimens from each grazing study was determined by oven drying at $60^{\circ} \mathrm{C}$ for $36 \mathrm{~h}$. The $\%$ carbon dry weight for each species was then estimated using the values reported in Ikeda \& Mitchell (1982). Schnack (1985) and Torres et al. (1994).

The grazing impact of meso- and macrozooplankton on microplankton was estimated by employing a modification of Frost's (1972) equation:

$$
F=\ln \left(C_{c} / C_{g}\right) V /(N t)
$$

where $F$ is clearance rate, $C_{c}$ is the final microplankton concentration in the control, $C_{11}$ is the final microplankton concentration in the grazing bottle, $V$ is the volume of the experimental container, $N$ is the number of grazers, and $t$ is the duration of the experiment.

The minimum carbon uptake (MCU; $\mu \mathrm{g} \mathrm{C}$ ind..$^{-1} \mathrm{~h}^{-1}$ ), representing the energy required to meet respiratory losses (Price et al. 1988), was then calculated for all the zooplankton species considered in the investigation. For Euphausia superba, MCU was calculated from the equation:

$$
\mathrm{MCU}=0.452 W^{0.975}
$$

where $W$ is the dry weight of an individual krill (HolmHansen \& Huntley 1984). MCU values for the Antarctic neritic krill E. crystallorophias and the amphipod Vibilia antarctica were estimated at $\sim 1.72$ (mean value) and $1.28 \%$ of their carbon body weight per day, respectively (Ikeda \& Bruce 1986). For the salp Salpa thompsoni, MCU was calculated assuming that indi- 
viduals require $-2.57 \%$ (mean value) of body carbon (dry weight) per day (Ikeda \& Bruce 1986). Finally, MCU values for the copepods and Thysanoessa macrura were estimated from the daily respiration rates available in the literature (Schnack 1985. Torres et al. 1994), assuming that $1 \mathrm{ml} \mathrm{O}=4.86 \mathrm{cal}$ and $1 \mathrm{mg}$ $\mathrm{C}=10 \mathrm{cal}$ (Vinogradov \& Shushkina 1987).

\section{RESULTS}

\section{Microplankton community}

A summary of the initial conditions for the zooplankton grazing experiments is presented in Table 1. During the incubations, mean chl a concentrations ranged between 0.187 and $1.410 \mu \mathrm{g} \mathrm{I}^{-1}$. Size-fractionation studies indicated that microphytoplankton $(>20 \mu \mathrm{m})$ dominated total chlorophyll, contributing between 54 and $70 \%$ of the total. Amongst the microphytoplankton, chain-forming species of the genera Chaetoceros and Nitzschia numerically dominated the cell counts. Also well represented were large diatoms such as Corethron criophilum, Rhizosolenia indica and the silico-flagellate Distephanus speculum. The single most abundant diatom species during the investigation was Chaetoceros dichaeta, which comprised $>40 \%$ of total cell counts in all the incubations. The concentration of the $<20 \mu \mathrm{m}$ chlorophyll fraction was always $<0.08 \mathrm{Mg} \mathrm{l}^{-1}$ and was dominated by unidentified nanoflagellates.

The microplankton (20 to $200 \mu \mathrm{m}$ ) fraction was entirely dominated by protozoans, with densities ranging from 1375 to 2690 cells l$^{-1}$ (Table 1). Among these, aloricate (Strombidium sp.) forms numerically dominated with densities ranging from 750 to $1375{\text { cells } 1^{-1}}^{-1}$ (size range $7.1 \times 10^{2}$ to $5.3 \times 10^{3} \mu \mathrm{m}^{3} ; \bar{x}=4.1 \times 10^{3} \mu \mathrm{m}^{3}$ ). Tintinnid abundances were always $<100$ cells $\mathrm{I}^{-1}$.
Dinoflagellates constituted the second most abundant group, with densities ranging between 525 and 750 cells $1^{-1}$. Protoperidinium, Amphisolenia and Goniaulax species were the main components of this group. Dinoflagellates volumes ranged from $2.5 \times 10^{2}$ to $5.6 \times$ $10^{3} \mu \mathrm{m}^{3}\left(\bar{x}=3.7 \times 10^{3} \mu \mathrm{m}^{3}\right)$. Abundances of the larger protozoans, such as acantharians and foraminiferans, were $<25$ cells $l^{-1}$ throughout the study. No metazoan larvae were recorded in the microplankton assemblages.

\section{Grazing experiments}

Among the copepods, feeding rates were highest for Metridia gerlachei and lowest for Rhincalanus gigas (Table 2). Indeed, analysis of variance indicates that the daily ration of $M$. gerlachei was significantly higher than those of the 3 other copepod species $(F=$ $12.4, \mathrm{p}<0.05)$. The specific carbon ingestion rates for $M$. gerlachei ranged between 9.0 and $14.8 \mu \mathrm{g} \mathrm{C}$ ind.$^{-1} \mathrm{~d}^{-1}\left(\bar{X}=13.6 \pm 5.2 \mu \mathrm{g} \mathrm{C}\right.$ ind.$\left.^{-1} \mathrm{~d}^{-1}\right)$, whilst for $R$. gigas the specific carbon ingestion rate ranged between 3.8 and $11.9 \mu \mathrm{g} C$ ind ${ }^{-1} \mathrm{~d}^{-1}(\bar{x}=8.5 \pm$ $3.1 \mu \mathrm{g} \mathrm{C}$ ind. ${ }^{-1} \mathrm{~d}^{-1}$ ). These rates correspond to a daily ration of between 5.7 and $13.6 \%$ body carbon $(\hat{x}=$ $9.1 \pm 3.4 \%$ ) for $M$. gerlachei and between 0.8 and $2.8 \%$ body carbon $(\bar{x}=2.0 \pm 0.7 \%)$ for $R$. gigas (Table 2).

The feeding rates of Calanoides acutus and Calanus propinquus corresponded to specific carbon ingestion rates of between 4.5 and $7.0 \mu \mathrm{g} \mathrm{C}$ ind.$^{-1} \mathrm{~d}^{-1}(\bar{x}=6.2 \pm$ $1.4 \mu \mathrm{g} \mathrm{C}$ ind..$^{-1} \mathrm{~d}^{-1}$ ) and between 9.8 and $11.7 \mu \mathrm{g} C$ ind ${ }^{-1} \mathrm{~d}^{-1}\left(\bar{x}=10.1 \pm 1.3 \mu \mathrm{g} \mathrm{C}\right.$ ind $\left.{ }^{-1} \mathrm{~d}^{-1}\right)$, respectively. These rates correspond to daily rations between 3.9 and $5.7 \%$ body carbon $(\bar{x}=4.9 \pm 0.9 \%)$ for $C$. acutus and between 4.2 to $6.4 \%$ body carbon $(5.5 \pm 0.9 \%)$ for C. propinquus (Table 2).

Table 1. Initial conditions of the carnivory experiments conducted using selected meso- and macrozooplankton species during the SAAMES IV cruise in the Marginal Ice Zone of the Lazarev Sea during austral summer (Dec/Jan) 1994/1995

\begin{tabular}{|c|c|c|c|c|c|}
\hline Stn & Temperature $\left({ }^{\circ} \mathrm{C}\right)$ & Zooplankton species & $\begin{array}{l}\text { Total chl a } \\
\text { conc. }\left(\mu g l^{-1}\right)\end{array}$ & $\begin{array}{c}\text { Microplankton } \\
\text { densities (cells } \text { l }^{-1} \text { ) }\end{array}$ & $\begin{array}{l}\text { No. grazers per } \\
\text { incubation bottle }\end{array}$ \\
\hline 1 & -1.15 & Euphausia superba & 0.709 & 1975 & 1 \\
\hline 2 & -1.27 & E. crystallorophias & 0.305 & 2280 & 1 \\
\hline 3 & -0.30 & Salpa thompsonj & 1.410 & 2690 & 1 \\
\hline 4 & -0.30 & Rhincalanus gigas & 0.907 & 1375 & $4-8$ \\
\hline 5 & -1.27 & Metridia gerlachei & 0.931 & 1750 & $4-8$ \\
\hline 6 & -0.86 & Calanoides acutus & 0.187 & 1875 & $4-8$ \\
\hline 7 & -0.54 & Calanus propinquus & 0.215 & 2125 & $4-8$ \\
\hline 8 & -1.15 & Vibilia antarctica & 0.247 & 1850 & $3-5$ \\
\hline 9 & -0.59 & Thysanoessa macrura & 0.654 & 1675 & $3-5$ \\
\hline 10 & -0.59 & $T$ macrura (juveniles) & 0.489 & 1800 & $3-5$ \\
\hline
\end{tabular}


Among the macrozooplankton species, feeding rates were highest for the tunicate Salpa thompsoni and lowest for the hyperiid Vibilia antarctica (Table 2). The specific carbon ingestion rate of $S$. thompsoni ranged between 152 and $356 \mu \mathrm{g} \mathrm{C}$ ind.$^{-1} \mathrm{~d}^{-1}(\bar{x}=232 \pm 83 \mu \mathrm{g} \mathrm{C}$ ind. ${ }^{-1} \mathrm{~d}^{-1}$, corresponding to an average daily ration of $72.7 \%$ body carbon (Table 2). For $V$. antarctica the specific carbon ingestion rate during the incubations ranged from 7.8 to $11.1 \mu \mathrm{g} \mathrm{C}$ ind.$^{-1} \mathrm{~d}^{-1}(\bar{x}=9.5 \pm 0.1 \mu \mathrm{g}$ $C$ ind.$\left.^{-1} \mathrm{~d}^{-1}\right)$, corresponding to an average daily ration of $\leq 0.4 \%$ body carbon (Table 2 ).

The specific carbon ingestion rates for adult Euphausia crystallorophias and Thysanoessa macrura varied between 124 and $247 \mu \mathrm{g} \mathrm{C}$ ind.$^{-1} \mathrm{~d}^{-1}(\bar{x}=158 \pm 61 \mu \mathrm{g} \mathrm{C}$ ind..$\left.^{-1} \mathrm{~d}^{-1}\right)$ and between 83 and $149 \mu \mathrm{g} \mathrm{C}$ ind..$^{-1} \mathrm{~d}^{-1}(\bar{x}=$ $125 \pm 19 \mu \mathrm{g} \mathrm{C}$ ind.$^{-1} \mathrm{~d}^{-1}$ ), respectively (Table 2 ). Based on these rates, the daily ration was equivalent to $1.2 \%$ body carbon for E. crystallorophias, and $1.1 \%$ for $T$. macrura (Table 2).

During the carnivory experiments conducted with juvenile Euphausia superba and juvenile Thysanoessa macrura, the specific carbon ingestion rates ranged between 50 and $301 \mu \mathrm{g} \mathrm{C}$ ind.$^{-1} \mathrm{~d}^{-1}(\bar{x}=187 \pm 88 \mu \mathrm{g} \mathrm{C}$ ind. $\left.{ }^{-1} \mathrm{~d}^{-1}\right)$ and between 34 and $68 \mu \mathrm{g} \mathrm{C}$ ind. ${ }^{-1} \mathrm{~d}^{-1}(\bar{x}=$ $54.7 \pm 3 \mu \mathrm{g} \mathrm{C}$ ind.$^{-1} \mathrm{~d}^{-1}$ ), respectively (Table 2 ). These rates correspond to an average daily ration of $3.1 \%$ body carbon for juvenile E. superba and $2.3 \%$ for juvenile $T$. macrura (Table 2 ).

\section{DISCUSSION}

The dominance of typical ice-associated microphytoplankton species such as Nitzschia and Chaetoceros suggests that the microphytoplankton community encountered during this study may have originated from ice melt (Heywood \& Whitaker 1984, Horner 1985). Dinoflagellates and ciliates numerically dominated the microplankton community, which is consistent with the results of previous studies in the MIZ (Garrison \& Buck 1989, Garrison et al. 1993). Our estimates of microzooplankton biomass ranged between

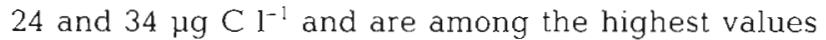
recorded for the Southern Ocean (for review see Garrison 1991). These elevated microzooplankton abundances are likely the result of increased phytoplankton biomass typically associated with the MIZ during summer.

During this study, all species of the meso- and macrozooplankton heavily consumed microplankton despite the presence of substantial chlorophyll concentrations (Tables $1 \& 2$ ). The MCU values representing energy required to meet respiratory losses, for the species used in this investigation are shown in Table 3 . From these data, it is evident that carbon derived from the consumption of microplankton contributed $>120 \%$ of the MCU in most species. Exceptions were Euphausia crystallorophias and Vibilia antarctica, in which

Table 2. Summary of carnivory experiments carried out with selected meso- and microzooplankton species feeding on microzooplankton at the ice-edge zone of the Lazarev Sea during austral summer (Dec/Jan) 1994/1995. Values shown are means $( \pm S D)$ for the 4 to 5 individuals in each experiment. DW: dry weight; CDW: carbon content of total dry weight; $F$ : clearance rate; I: ingestion rate; $C$ : carbon specific ingestion rate

\begin{tabular}{|c|c|c|c|c|c|c|}
\hline & $\begin{array}{l}\text { DW } \\
\text { (mg) }\end{array}$ & $\begin{array}{l}\text { CDW } \\
(\mathrm{mg})\end{array}$ & $\begin{array}{c}F \\
\left(\mathrm{ml} \text { ind. }{ }^{-1} \mathrm{~h}^{-1}\right)\end{array}$ & $\frac{I}{\left(\text { cells ind. } .^{-1} \mathrm{~d}^{-1}\right)}$ & $\underset{\left(\mu g \text { ind } .^{-1} d^{-1}\right)}{C}$ & $\begin{array}{c}\text { Ration } \\
(\% \text { body } C)\end{array}$ \\
\hline $\begin{array}{l}\text { Rhincalanus gigas } \\
(\mathrm{n}=5)\end{array}$ & $0.9( \pm 0.1)$ & $0.4( \pm 0.001)$ & $12( \pm 7.7)$ & $5( \pm 0.4)$ & $8.5( \pm 3.1)$ & $2.0( \pm 0.7)$ \\
\hline $\begin{array}{l}\text { Metridia gerlachei } \\
(\mathrm{n}=4)\end{array}$ & $0.3( \pm 0.1)$ & $0.2( \pm 0.002)$ & $7( \pm 2.3)$ & $8( \pm 3)$ & $13.6( \pm 5.2)$ & $9.1( \pm 3.4)$ \\
\hline $\begin{array}{l}\text { Calanoides acutus } \\
(\mathrm{n}=5)\end{array}$ & $0.3( \pm 0.1)$ & $0.1( \pm 0.001)$ & $7( \pm 1.7)$ & $6( \pm 1)$ & $6.2\{ \pm 1.4\}$ & $4.9( \pm 0.9)$ \\
\hline $\begin{array}{l}\text { Calanus propinquus } \\
(\mathrm{n}=5)\end{array}$ & $0.4( \pm 0.2)$ & $0.2( \pm 0.003)$ & $8( \pm 1.7)$ & $6( \pm 0)$ & $10.1( \pm 1.3)$ & $5.5( \pm 0.9)$ \\
\hline $\begin{array}{l}\text { Euphausia superba } \\
\text { (juveniles; } n=8 \text { ) }\end{array}$ & $13.6( \pm 0.4)$ & $6.1( \pm 0.3)$ & $318( \pm 77)$ & $624( \pm 301)$ & $187.5( \pm 88)$ & $3.1( \pm 0.2)$ \\
\hline $\begin{array}{l}\text { E. crystallorophias } \\
(\mathrm{n}=8)\end{array}$ & $29.9( \pm 1.3)$ & $13.5( \pm 0.5)$ & $133( \pm 53)$ & $449( \pm 9)$ & $157.9( \pm 61)$ & $1.2( \pm 0.3)$ \\
\hline $\begin{array}{l}\text { Salpa thompsoni } \\
(\mathrm{n}=8)\end{array}$ & $2.4( \pm 0.6)$ & $0.3( \pm 0.1)$ & $253( \pm 26)$ & $781( \pm 280)$ & $232.6( \pm 83)$ & $72.7( \pm 4.3)$ \\
\hline $\begin{array}{l}\text { Vibilia antarctica } \\
(\mathrm{n}=4)\end{array}$ & $5.1( \pm 1.5)$ & $2.5( \pm 0.2)$ & $6( \pm 2)$ & $132( \pm 24)$ & $9.5( \pm 0.1)$ & $0.4( \pm 0.1)$ \\
\hline $\begin{array}{l}\text { Thysanoessa macrura } \\
\text { (adults; } n=4 \text { ) }\end{array}$ & $23.0( \pm 4.6)$ & $11.4( \pm 1.9)$ & $733( \pm 35)$ & $741( \pm 65)$ & $125( \pm 33)$ & $1.1( \pm 0.2)$ \\
\hline $\begin{array}{l}T \text {. macrura } \\
\text { (juveniles } \mathrm{n}=2 \text { ) }\end{array}$ & $4.8( \pm 2.5)$ & $2.4( \pm 1.1)$ & $21( \pm 6)$ & $206( \pm 63)$ & $54.7( \pm 3)$ & $2.3( \pm 0.4)$ \\
\hline
\end{tabular}


Table 3. Daily carbon ingestion rates expressed as \% of minimum carbon uptake (MCU) for respiratory requirements of selected meso- and macrozooplankton species obtained from leeding experiments conducted within the ice-edge zone of the Lazarev Sea during austral summer (Dec/Jan) 1994/1995

\begin{tabular}{|lcc|}
\hline & MCU (\% body $\left.\mathrm{C} \mathrm{d}^{-1}\right)$ & $\% \mathrm{MCU}^{-1}$ \\
\hline Rhincalanus gigas & 1.65 & 122 \\
Metridia gerlachei & 1.14 & 721 \\
Calanoides acutus & 3.95 & 155 \\
Calanus propinquus & 2.96 & 185 \\
Euphausia superba & 1.02 & 135 \\
E. crystallorophias & 1.72 & 68 \\
Thysanoessa macrura & 0.85 & 137 \\
(juveniles) & 0.82 & \\
T. macrura & & \\
(adults) & 2.57 & 362 \\
Salpa thompsoni & 1.28 & 30 \\
Vibilia antarctica & & \\
\hline
\end{tabular}

microplankton contributed only 68 and $30 \%$ of MCU, respectively (Table 3 ). This indicates that, with the exception of the Antarctic neritic krill and the hyperiid, all species of zooplankton examined in this study can meet their minimum metabolic requirements by feeding on microplankton. It should be noted that MCU values for the macrozooplankton were determined from the dry weight of samples preserved in formalin. No correction factors were applied to the dry weights to account for losses due to formalin preservation. This may have resulted in the over-estimation of the contribution of microplankton to the MCU of the larger zooplankton.

Among the copepods, daily rations of Rhincalanus gigas feeding on microplankton were the lowest recorded during this investigation (Table 2). Analysis of variance indicated that daily rations for this species were significantly lower than for the other 3 copepods $(F=12.83, p<0.001)$. There is some evidence in the literature that $R$. gigas exhibits low feeding and respiration rates and has low growth efficiencies when incubated in vitro (Conover \& Huntley 1991, Atkinson et al. 1992, Drits \& Pasternak 1993). The low daily rations obtained during this study probably reflect those previously reported. The daily rations of the 3 other copepods also did not differ substantially from those reported in the literature (Conover \& Huntley 1991., Atkinson et al. 1992, Atkinson 1994).

The contribution of microplankton to the total carbon ration of the 4 copepod species used in this investigation was estimated from the average daily carbon rations reported in Conover \& Huntley (1991). Microplankton accounted for $\sim 17 \%$ of the daily carbon ration in Calanoides acutus and Rhincalanus gigas while in Calanus propinquus and Metridia gerlachei the microplankton contribution was 19 and $24 \%$, respectively. From these results, it is clear that the low daily rations of $R$. gigas reflect the normally low metabolic characteristics of this species (see above). Our estimates of daily ration, calculated by employing the average daily rations of Conover \& Huntley (1991), compare well with results obtained in a recent study conducted by Atkinson (1994)

The daily ration of Vibilia antarctica was the lowest found during the entire investigation, corresponding to $<0.5 \%$ body carbon (Table 2 ). Gut content analyses have shown that $V$. antarctica preferentially feeds on large crustaceans such as euphausiids (Hopkins 1985). During this study, however, the carnivory experiments were conducted in the absence of prey $>200 \mu \mathrm{m}$. The data indicate that $V$. antarctica feeds on microzooplankton only to supplement its dietary requirements while larger prey items, such as euphausiids and copepods, are the main source of carbon for this hyperiid

The daily ration of the juvenile Thysanoessa macrura was more than twice that of adults (Table 2). According to Nordhausen (1994), T. macrura can be considered a truly omnivorous species. Our data suggest, however, that the relative importance of microplankton in the diet of $T$ macrura changes with life stage. It is of particular interest that, the daily ration of juvenile Euphausia superba (on average $61 \%$ of the total carbon requirement) was amongst the highest recorded during the entire investigation (Table 2). These data suggest that juvenile macrozooplankton are more efficient grazers of microplankton than adults.

In this study, the tunicate Salpa thompsoni had the highest specific carbon ingestion rates (Table 2). Although these rates are in the same range as those observed by Reinke (1987) and Huntley et al. (1989) within the same species, they are generally lower than those of tunicates of similar size cited in the literature (see Huntley et al. 1989). Reductions in salp clearance rates may result from bottling effects or the inability of salps to regulate their feeding rates. A recent parallel study has shown that the feeding efficiency of $S$. thompsoni decreases dramatically at chlorophyll concentrations $>1 \mu \mathrm{g} \mathrm{l} \mathrm{l}^{\mathrm{l}}(\mathrm{R}$. Perissinotto \& E. Pakhomov unpubl.). It is also worth noting that another study conducted in the Southern Ocean reported filtration rates for S. thompsoni ranging between 410 and $600 \mathrm{mll}$ ind $^{-1} h^{-1}$ in regions where chlorophyll concentrations were $<0.6 \mu \mathrm{g} \mathrm{I}^{-1}$ (Drits \& Semenova 1989). Using an in situ technique, Perissinotto \& Pakhomov (unpubl.) obtained rates averaging $430 \mathrm{ml}$ ind $\mathrm{d}^{-1} \mathrm{~h}^{-1}$ for salps in the size range 1 to $5 \mathrm{~cm}$ length. These data suggest that the carbon specific ingestion rates obtained for the salp during this investigation can probably be regarded as conservative. 
The daily rations of the macrozooplankton species used in the incubations are shown in Table 2. Assuming that all the euphausiids used in this investigation require $\sim 5 \%$ of body carbon per day to meet their entire metabolic costs (Clarke \& Morris 1983), carbon derived from the consumption of microplankton contributed $23 \%$ of total carbon requirements for Euphausia crystallorophias and $61 \%$ for E. superba juveniles. For adult Thysanoessa macrura, carbon derived from microplankton contributed $21 \%$ of the total while for juveniles it accounted for $45 \%$ of the total. These data clearly indicate that the consumption of phytoplankton still represented an important carbon source for both the copepods and the euphausiids during this investigation. The contribution of microplankton to total carbon requirements for the salps was, however, higher. Assuming that salps require daily $-21 \%$ of their body carbon to meet their metabolic demands, carbon derived from the consumption of microplankton would have contributed $>300 \%$ of their total requirements.

The tunicate Salpa thompsoni had the highest daily ration of all zooplankton species investigated (Table 2 ). Salps have been shown to retain all particles $>2 \mu \mathrm{m}$ with almost $100 \%$ efficiency and produce compact, quick sinking faecal pellets with high carbon content. Salps are, therefore, efficient agents in transferring carbon from surface waters to depth (Fortier et al. 1994). Salps grazing on micro- and bactivorous nanoplankton may thus represent an important source of carbon that can be transferred from the microbial loop to the long-living pool. Recently, it has been shown that salp abundances in some regions of the high Antarctic have increased in response to localised warming in seawater temperature, at times dominating total zooplankton biomass (Pakhomov 1991). A recent in situ grazing study has demonstrated that $S$. thompsoni is able to consume up to $100 \%$ of the daily phytoplankton production (Perissinotto \& Pakhomov unpubl.). Salps may, therefore, play a key role in the Southern Ocean carbon pump. In the case of the copepods, on the other hand, although they exhibited relatively high daily rations (Table 2 ), their contribution to carbon flux is reduced because they often re-ingest their own faecal material (Fortier et al, 1994).

It is clear that during the summer 1994/1995 microplankton represented an important source of carbon for all the meso- and macrozooplankton species studied (Table 2). These results are consistent with those obtained during similar studies conducted in different regions of the Southern Ocean (Conover \& Huntley 1991, Atkinson 1994, 1995). It should be noted, however, that our estimates do not provide precise data on the contribution of heterotrophic carbon to total daily intake since some of the dinoflagellate taxa represented in the protozoan assemblages were auto- trophic. Also, daily rations derived from the consumption of protozoans may have been severely underestimated since the contribution of the $<20 \mu \mathrm{m}$ (nanoplankton) component was not considered during this investigation. Studies conducted in the Southern Ocean have shown that nano-heterotrophs may comprise up to $20 \%$ of total plankton biomass (Garrison et al. 1991, Sorokin 1993). Further inaccuracies in estimates of microplankton contribution to daily ration of larger zooplankton during this study may have resulted from the experimental procedure. For example, the estimates of carbon ingestion were derived from the biovolume of microzooplankton cells fixed with Lugol's solution. Recent studies have shown that cell shrinkage in samples fixed with Lugol's solution may be as high as $25 \%$ (Leakey et al. 1994). Finally, the removal of water samples for the determination of microplankton cell counts at the onset of the incubation may have resulted in inaccuracies associated with lysis of protists or changes in feeding behaviour due to increased turbulence in the incubation chambers (Saiz et al. 1992).

Seasonal grazing rates of larger zooplankton feeding on microzooplankton are poorly documented (for review see Conover \& Huntley 1991). Recent studies conducted during winter in the Weddell Sea and in early summer in the vicinity of Elephant Island (Antarctica) have shown that energy derived from the consumption of phytoplankton alone cannot meet the daily metabolic requirements of copepods (Bathmann et al. 1993, Drits et al. 1994). Alternative sources of food have been suggested to meet copepod energetic demands, including detritus and protozoans (Bathmann et al. 1993). A carnivorous feeding mode in copepods has been suggested as a possible mechanism allowing them to remain active during winter when chlorophyll concentrations are low (Atkinson 1994). Indeed, another recent study conducted in the vicinity of the Antarctic Peninsula has shown that carnivory by zooplankton probably represents the dominant trophic mode during winter (Huntley \& Nordhausen 1995). Alternatively, zooplankton may utilise their lipid and protein supplies to overwinter (Hagen et al. 1993). Microzooplankton appear to represent an important carbon source for larger zooplankton in both summer and winter. The ability of metazoans to consume both autotrophic and heterotrophic prey may be a necessary adaptation to the seasonality and patchiness of food distribution in the Antarctic (Atkinson 1994). During winter, in the absence of microphytoplankton (Garrison et al. 1993), the predation impact of zooplankton on microzooplankton can be expected to increase. These shifts may have important consequences for the biological pump. Microzooplankton are recognised as major consumers of phytoplankton production in the 
Southern Ocean (Garrison et al. 1993, Kivi \& Kuosa 1994, Froneman \& Perissinotto 1996, in press). Predation by metazoans as a consequence, may reduce the high grazing impact that microzooplankton generally exert on the phytoplankton.

Acknowledgements. We are grateful to the Department of Environmental Affairs \& Tourism, South Africa, and to Rhodes University for providing funds and facilities for this study. We also acknowledge the master and crew of the 'SA Agulhas' Finally we thank K. Neke for her valuable assistance at sea.

\section{LITERATURE CITED}

Atkinson A (1994) Diets and feeding selectivity among the epipelagic copepod community near South Georgia in summer. Polar Biol 14:551-560

Atkinson A (1995) Omnivory and feeding selectivity in five copepod species during spring in the Bellingshausen Sea, Antarctica. J Mar Sci 52:385-396

Atkinson A, Shreeve RS (1995) Response of the copepod community to a spring bloom in the Bellingshausen Sea. Deep Sea Res 42:1291-1312

Atkinson A, Ward P, Williams R, Poulet SA (1992) Feeding rates and vertical migration of copepods near South Georgia: comparison of shelf and oceanic sites. Mar Biol 114 $49-56$

Bathmann UV, Makarov RR, Spiridonov VA, Rohardt G (1993) Winter distribution and overwintering strategies of the Antarctic copepod species Calanoides acutus, Rhincalanus gigas and Calanus propinquus (Crustacea. Calanoida) in the Weddell Sea. Polar Biol 13:333-346

Bjornsen PK, Kuparinen J (1991) Growth and herbivory by heterotrophic dinoflagellates in the Southern Ocean, studjed by microcosm experiments. Mar Biol 109:397-405

Boltovskoy D, Alder VA, Spinelli F (1989) Summer Weddell Sea microplankton: assemblage structure, distribution and abundance, with special emphasis on the Tintinnina. Polar Biol 9:447-456

Burkill PH, Edwards S, Sleigh MA (1995) Microzooplankton and their role in controlling phytoplankton growth in the marginal ice zone of the Bellingshausen Sea. Deep Sea Res 42:1277-1290

Clarke A, Morris DJ (1983) Towards an energy budget for krill: the physiology and biochemistry of Euphausia superba Dana. Polar Biol 2:69-86

Conover RJ, Huntley M (1991) Copepods in ice covered seas-distributions, adaptations to seasonally limited food, metabolism, growth patterns and life cycle strategies in polar stas. J Mar Syst 2.1-41

Drits AV, Pasternak AF (1993) Feeding of the dominant species of the Antarctic herbivorous zooplankton. In: Voronina NM (ed) Pelagic ecosystems of the Southern Ocean. Nuaka Press, Moscow, p 250-259 (in Russian)

Drits AV, Pasternak AF, Kosobokova KN (1994) Physiological characteristics of the Antarctic copepod Calanoides acutus during late summer in the Weddell Sea. Hydrobiologia 292:201-207

Drits AV, Semenova TN (1989) Trophic characteristics of major planktonic phytophages from the South Shetland Islands durnng early spring. In: Ponomareva LA (ed) Complex investigations of the pelagic zone of the Southern Ocean. Shirshov Instutute Oceanology Publishers, Moscow, p 66-78 (in Russian)
Fortier L, LeFevre J, Legendre L (1994) Export of biogenic carbon to fish and to the deep ocean: the role of large planktonic microphages. J Plankton Res 16:809-839

Froneman PW, Perissinotto R (1996) Structure and grazing of the microzooplankton communities of the Subtropical Convergence and a warm-core eddy in the Atlantic sector of the Southern Ocean. Mar Ecol Prog Ser 135:237-245

Froneman PW, Perissinotto R (in press) Seasonal variations in microzooplankton grazing and carbon flux in the region of the Subtropical Convergence. Mar Biol

Frost BW (1972) Effects of size and concentration of food particles on the feeding behaviour of the marine planktonic copepod Calanus pacificus. Limnol Oceanogr 17:805-815

Garrison DL (1991) An overview of the abundance and role of protozooplankton in Antarctic waters. J Mar Syst 2: 317- 331

Garrison DL, Buck KR (1989) Protozooplankton in the Weddell Sea, Antarctica: abundance and distribution in the ice edge zone. Polar Biol 9:341-351

Garrison DL, Buck KR, Gowing MM (1991) Plankton assemblages in the ice edge zone of the Weddell Sea during austral winter. J Mar Syst 2:123-130

Garrison DL, Buck KR, Gowing MM (1993) Winter plankton assemblages in the ice edge zone of the Weddell and Scotia Seas: composition, biomass and spatial distributions. Deep Sea Res 40:311-338

Gifford DJ (1993) Consumption of protozoa by copepods feeding on natural microplankton assemblages. In: Kemp PF, Sherr BF. Sherr EB, Cole JJ (eds) Handbook of methods in aquatic microbial ecology. Lewis Publishers, Boca Raton, p $723-729$

Gifford DJ, Dagg MJ (1988) Feeding of the estuarine copepod Acartia tonsa Dana: carnivory vs. herbivory in natural microplankton assemblages. Bull Mar Sci 43:458-468

Gifford DJ, Dagg MJ (1990) The microzooplankton-mesozooplankton link: consumption of planktonic protozoa by the calanoid copepods Acartia tonsa Dana and Neocalanus plumchrus Murukawa. Mar Microb Food Webs 5:161-177

Goeyens L, Tregeur P, Lancelot C, Mathot S, Becquevort S, Morvan J, Dehairs F, Baeyens W (1991) Ammonium regeneration in the Scotia-Weddell Confluence area during spring 1988. Mar Ecol Prog Ser 78:241-252

Hagen W, Kattner G, Graeve M (1993) Calanoides acutus and Calanus propinquus, Antarctic copepods with different lipid storage modes via wax esters or triacylglycerols. Mar Ecol Prog Ser 97:135-142

Heywood RB, Whitaker TM (1984) Marine flora. In: Laws RM (ed) Antarctic ecology, Vol 2. Academic Press, London, p 373-419

Holm-Hansen O, Huntley M (1984) Feeding requirements of krill in relation to food sources. J Crust Biol 4:156-178

Holm-Hansen O, Riemann B (1978) Chlorophyll-a determination: improvements in methodology. Oikos 30:438-447

Hopkins TL (1985) Food web of the Antarctic ecosystem. Mar Biol 89:197-211

Hopkins TL, Ainley DG, Torres JJ, Lancraft TM (1993) Trophic structure in open waters of the marginal ice zone in the Scotia-Weddell confluence region during spring 1983. Polar Biol 13:389-397

Hopkins TL, Torres JJ (1989) Midwater food web in the vicinity of a marginal ice zone in the western Weddell Sea. Deep Sea Res 36:543-560

Horner RA (1985) Sea ice biota. CRC Press, Boca Raton

Huntley ME, Nordhausen W (1995) Ammonium cycling by Antarctic zooplankton in winter. Mar Biol 121:457-467

Huntley ME, Sykes PF, Martin V (1989) Biometry and trophodynamics of salp Salpa thompsoni Foxton (Tunicata: Thali- 
acea) near the Antarctic Peninsula in austral summer, 1983-1984. Polar Biol 10:59-70

Ikeda T, Bruce B (1986) Metabolic activity and the elemental composition of krill and other zooplankton from Prydz Bay, Antarctica, during early summer (NovemberDecember). Mar B10l 92:545-555

Ikeda T, Mitchell AW (1982) Oxygen uptake, ammonia excretion and phosphate excretion by krill and other Antarctic zooplankton in relation to their body size and chemical composition. Mar Biol 71:283-298

Jeong HJ (1994) Predation effects of the calanoid copepod Acartia tonsa on a population of the heterotrophic dinoflagellate Protoperidinium cf. divergens in the presence of co-occurring red-tide dinoflagellate prey. Mar Ecol Prog Ser 111:87-94

Kivi K, Kuosa H (1994) Late winter microbial communities in the western Weddell Sea (Antarctica). Polar Biol 14: 389-399

Leakey JG, Burkill PH, Sleigh MA (1994). A comparison of fixatives for the estimation of abundance and biovolume of marine planktonic ciliate populations. J Plankton Res 16 : $375-389$

Longhurst AR (1991) Role of the marine biosphere in the global carbon cycle. Limnol Oceanogr 36(8):1507-1526

Nordhausen W (1994) Winter abundance and distribution of Euphausia superba, E. crystallorophias and Thysanoessa macrura in Gerlache Strait and Crystal Sound, Antarctica. Mar Ecol Prog Ser 109:131-142

Pakhomov EA (1991) Antarctic macroplankton and the nutrition of coastal fishes. PhD thesis, PP Shirshov Institute of Oceanology, Russian Academy of Sciences, Moscow

Pakhomov EA, Perissinotto R, Froneman PW (in press) Abundance, vertical migration and trophodynamics of Euphausia crystallorophias in the shelf region of the Lazarev Sea during austral spring and summer. J Mar Syst

Paranjape MA (1990) Microzooplankton herbivory on the Grand Bank (Newfoundland, Canada): a seasonal study. Mar Biol 107:321-328

Perissinotto R (1992) Mesozooplankton size-selectivity and grazing impact on the phytoplankton community of the Prince Edward Archipelago. Mar Ecol Prog Ser 79: $243-258$

Pierce RW, Turner JT (1992) Ecology of planktonic ciliates in marine food webs. Rev Aquat Sci 6:139-181

Price HJ, Boyd KR, Boyd CM (1988) Omnivorous feeding behaviour of the Antarctic krill Euphausia superba. Mar Biol 97:67-77

Probyn TA (1987) Ammonium regeneration by microplankton in an upwelling environment. Mar Ecol Prog Ser 37.53-64

Putt M. Stoecker DK (1989) An experimental determined carbonvolume ration of marine 'oligotrichous' ciliates

This article was submitted to the editor from estuarine and coastal water. Limnol Oceanogr 34: $1097-1103$

Reid FMH (1983) Biomass estimation of components of marine nanoplankton and picoplankton by the Utermöhl settling technique. J Plankton Res 5:235-252

Reinke M (1987) On the feeding and the locomotory physiology of Salpa thompsonı and Salpa fusiformis. Rep Pol Res 36:1-88

Saiz E, Alcaraz M, Paffenhofer GA (1992) Effects of small scale turbulence on feeding rate and gross-growth efficiency of three Acartia species. J Plankton Res 14: 1085-1097

Schnack SB (1985) Feeding by Euphausia superba and copepod species in response to varying concentrations of phytoplankton. In: Siegfried WR, Condy PR, Laws RM (eds) Antarctic nutrient cycles and food webs. SpringerVerlag, Berlin p 311-323

Sherr BF, Sherr EB (1984) Role of heterotrophic protozoa in carbon and energy flow in aquatic ecosystems. In: Klug MJ, Reddy CA (eds) Current perspectives in microbial ecology. Am Soc Microbiol, Washington, DC, p 412-423

Sime-Ngando T, Juniper K, Veznia A (1992) Ciliated protozoan communities over Cobb Seamount: increase in biomass and spatial patchiness. Mar Ecol Prog Ser 89:37-51

Sorokin PY (1993) Planktonic ciliates in the Antarctic waters. In: Klekowski RZ, Opalinski KW (eds) The Second PolishSoviet Antarctic Symposium. Institute of Ecology Publishing Office, Polish Academy of Sciences, Dziekanow Lesny p $89-94$

Stoecker DK, Capuzzo JM (1990) Predation on protozoa: its importance to zooplankton. J Plankton Res 12:891-908

Stoecker DK, Verity PG, Michaels AE, Davies LH (1987) Feeding by larval and post-larval ctenophores on microzooplankton. J Plankton Res 9:667-683

Tanoue E, Hara S (1986) Ecological implications of faecal pellets produced by the Antarctic krill Euphausia superba in the Antarctic Ocean. Mar Biol 91:359-369

Tiselius P (1989) Contribution of aloricate ciliates to the diet of Acartia clausi and Centropages hamatus in coastal waters. Mar Ecol Prog Ser 56:49-56

Torres JJ, Aarset AV, Donnelly J, Hopkins TL, Lancraft TM, Ainley DG (1994) Metabolism of Antarctic micronektonic crustacea as a function of depth of occurrence and season. Mar Ecol Prog Ser 113:207-219

Vinogradov ME, Shushkina EA (1987) Functioning of the planktonic communities in the epipelagic zone of the ocean. Nauka Press, Moscow (in Russian)

Wickham SA (1995) Trophic relations between cyclopoid copepods and ciliated protists: complex interactions link the microbial and classic food webs. Limnol Oceanogr 40: $1173-1181$

Manuscript first received: February 14, 1996

Revised version accepted: August 1, 1996 